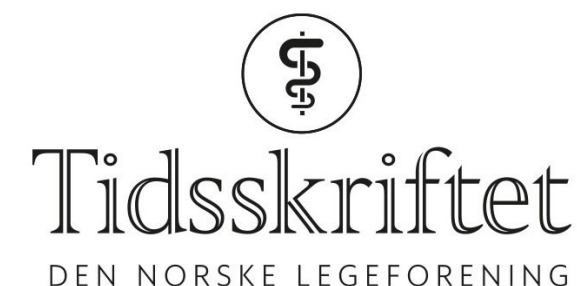

DEN NORSKE LEGEFORENING

\title{
Oppdateringer av nasjonal traumeplan
}

DEBATT

\section{CHRISTINE GAARDER}

Christine Gaarder er ph.d., spesialist i gastroenterologisk kirurgi, overlege og leder for Avdeling for traumatologi ved Oslo universitetssykehus, Ullevål, og professor ved Institutt for klinisk medisin ved Universitetet i Oslo.

Forfatteren har fylt ut ICMJE-skjemaet og oppgir ingen interessekonflikter.

\section{THOMAS GEISNER}

Thomas Geisner er spesialist i thoraxkirurgi, overlege og leder for Traumesenteret ved Haukeland universitetssjukehus.

Forfatteren har fylt ut ICMJE-skjemaet og oppgir ingen interessekonflikter.

\section{STIG EGGEN HERMANSEN}

Stig Eggen Hermansen er ph.d., spesialist i thoraxkirurgi og i karkirurgi, overlege ved Hjerte-, lungeog karkirurgisk avdeling og leder for traumeseksjonen ved Universitetssykehuset Nord-Norge. Forfatteren har fylt ut ICMJE-skjemaet og oppgir ingen interessekonflikter.

\section{BENT ̊̊GE ROLANDSEN}

Bent Åge Rolandsen er spesialist i karkirurgi, overlege og avdelingssjef for Regionalt traumesenter ved St. Olavs hospital.

Forfatteren har fylt ut ICMJE-skjemaet og oppgir ingen interessekonflikter.

\section{TONE MARGRETHE SAXEBØLL SLÅE}

Tone Margrethe Saxebøll Slåke er sykepleier og leder for Nasjonal kompetansetjeneste for traumatologi ved Oslo universitetssykehus, Ullevål.

Forfatteren har fylt ut ICMJE-skjemaet og oppgir ingen interessekonflikter.

\section{TORBEN WISBORG}

E-post: torben@wisborg.net

Torben Wisborg er spesialist i anestesiologi, forskningsleder i Nasjonal kompetansetjeneste for traumatologi ved Oslo universitetssykehus, Ullevål, professor ved Akuttmedisinsk-anestesiologisk forskningsgruppe ved Universitetet i Troms $\emptyset$ og overlege ved Akuttmedisinsk avdeling ved Finnmarkssykehuset, Klinikk Hammerfest. Han er medlem av Tidsskriftets redaksjonskomité. Forfatteren har fylt ut ICMJE-skjemaet og oppgir ingen interessekonflikter.

Det nasjonale systemet for behandling av alvorlig skadde trenger løpende revisjon. Det er tid for den første store gjennomgangen av planen, og nå er det mulighet for å komme med innspill.

Behandlingen av alvorlige skader bygger på forhåndsdefinerte planer. Erfaringen fra en rekke land har vist at et traumesystem gir bedre pasientutfall. Dette har fagpersoner visst 
lenge, og de regionale helseforetakene iverksatte tidlig etter opprettelsen et arbeid der målet var en nasjonal plan som skulle beskrive behandling fra skadested til ferdig rehabilitering.

Norges første nasjonale traumeplan kom i 2006 (1). Den ble vedtatt i litt ulike versjoner av de regionale helseforetakene, men ble stort sett implementert i alle helseforetak $(2,3)$. Planen ble utgitt som bok/hefte, og ble først senere tilgjengelig som et låst dokument på nett. Det tok ti år før en revisjon forelå.

Revisjonen av planen ble utført av Nasjonal kompetansetjeneste for traumatologi (NKTTraume) på oppdrag fra fagdirektørene i de regionale helseforetakene. Gruppen som gjennomførte revisjonen, besto av representanter for alle regionale helseforetak og alle ledd i behandlingskjeden samt en brukerrepresentant.

Når revisjonsforslag er godkjent, kan de umiddelbart iverksettes

Den reviderte planen ble vedtatt i samme versjon av alle de fire regionale helseforetakene i 2016-17. Den ble spredt raskt, og er nå i bruk i alle helseforetak (4). Planen er tilgjengelig både på nett (5) og som egen, gratis app som lastes ned via leverandøren MyMedicalBooks i App Store og Google Play.

Allerede fra planen ble levert fagdirektørene i de regionale helseforetakene og til den ble vedtatt, hadde utviklingen innen traumebehandling gått videre, blant annet med godkjenning av spesifikt antidot mot et av de nye direktevirkende orale antikoagulasjonsmidlene. Derfor har NKT-Traume inngått avtale med fagdirektørene for de regionale helseforetakene om løpende å samle forslag til revisjon.

Revisjonsforslagene gjennomgås av kompetansetjenestens nettverk av fagpersoner, og skal deretter drøftes med fagdirektørene for de regionale helseforetakene, som er eiere av planen. Når revisjonsforslag er godkjent, kan de umiddelbart iverksettes fordi appen og nettstedet som huser traumeplanen, er enkle å oppdatere. De inneholder begge også en logg som beskriver hva som er endret når.

Traumeplanen har nå vært tilgjengelig siden 2017, men den ble først publisert som app og nettsted våren 2019. Vi samler nå innspill til første runde av den løpende revisjonen, som naturlig nok vil bli mer omfattende, og der alle funksjoner som var involvert i det opprinnelige arbeidet, vil delta i vurderingen av forslagene. Hvert av de regionale helseforetakene har sin egen organisasjon for traumeomsorg, og innspill kan leveres gjennom egen organisasjon eller direkte til NKT-Traume (post@traumatologi.no).

Nasjonal kompetansetjeneste for traumatologi samler arbeidsgruppen bak planen i januar 2020 for å fremme et gjennomarbeidet og konsensusbasert forslag til fagdirektørene. Selv om planen skal revideres løpende, blir dette den første store gjennomgangen, og vi oppfordrer alle med synspunkter på planen og revisjonsforslag om å sende dem til kompetansetjenesten eller regional traumeorganisasjon.

LITTERATUR:

1. Helse $\oint ø r-\emptyset$ st. Organisering av behandlingen av alvorlig skadde pasienter. Traumesystem. http://traumatologi.no/wp-content/uploads/2014/o9/Traumesystem-20o6-endelig-rapport.pdf Lest 5.8.2019.

2. Kristiansen T, Ringdal KG, Skotheimsvik T et al. Implementation of recommended trauma system criteria in south-eastern Norway: a cross-sectional hospital survey. Scand J Trauma Resusc Emerg Med 2012; 20: 5. [PubMed][CrossRef]

3. Dehli T, Gaarder T, Christensen BJ et al. Implementation of a trauma system in Norway: a national survey. Acta Anaesthesiol Scand 2015; 59:384-91. [PubMed][CrossRef]

4. Wisborg T, Gaarder C, Geisner T et al. Ny nasjonal traumeplan. Tidsskr Nor Legeforen 2017; 137: 1587. [CrossRef] 
5. Traumeplan NKT. www.traumeplan.no Lest 29.10.2019.

Publisert: 18. november 2019. Tidsskr Nor Legeforen. DOI: 10.4045/tidsskr.19.0642 Mottatt 9.10.2019, godkjent 21.10.2019.

(C) Tidsskrift for Den norske legeforening 2020. Lastet ned fra tidsskriftet.no 